\title{
Perspective
}

\section{EFFORTS TO INCREASE INTEREST IN VASECTOMY FAMILY PLANNING ACCEPTORS}

\section{Agus Sulistyowati ${ }^{*}$, Ni Putu Widari ${ }^{2}$}

1 Kerta Cendekia Nursing Academy, Sidoarjo

Lingkar Timur Road, Rangkah Kidul Village, Sidoarjo Sub-District, Sidoarjo District, East Java Province, Indonesia 61234

${ }^{2}$ STIKES William Booth, Surabaya

Jl. Cimanuk No.20, Darmo, Kec. Wonokromo, Kota SBY, Jawa Timur 60241

\section{*Correspondence: Agus Sulistyowati \\ Kerta Cendekia Nursing Academy, Sidoarjo \\ Lingkar Timur Road, Rangkah Kidul Village, Sidoarjo Sub-District, Sidoarjo District, East Java Province, Indonesia 61234}

Email: agussulistyowati78@gmail.com

\section{Article Info:}

Received: 7 October 2020

Revised: 8 November 2020

Accepted: 8 November 2020

\section{DOI:}

https://doi.org/10.36720/nhjk.v9i2.214

\begin{abstract}
Family planning is one of the four pillars of safe motherhood, which plays a role in ensuring that each person or partner has access to family planning information and services so that they can plan the right time for pregnancy, the length of pregnancy, and the number of children. The factor of the lack of success of the family planning program cannot be separated from the lack of interest in the community, especially couples of childbearing age (PUS) using contraceptives. of them still consider the high cost and not easy to use the stable contraceptive method. The steady method of contraception is a method of contraception which in men is called a vasectomy. Based on data from the 2017 Indonesian Demographic and Health Survey (IDHS), the percentage of male contraceptives using condoms is $2.5 \%$. There are several factors that make men reluctant to take family planning, including low knowledge and understanding of reproductive rights, limited equipment male contraception, social conditions, rumors about vasectomy, and negative condom use (Depkes RI, 2010).

According to Notoatmodjo (2010), knowledge is a big factor in increasing men's participation in family planning. One's knowledge of health can be obtained through health education, Ali (2000) revealed that health education is an educational activity carried out by spreading messages, instilling confidence, so that people are not only aware, know and understand, but also want and can do something. advice that has to do with health. Learning media or health education media that can and quickly deliver health messages include: television, radio, newspapers/ magazines, posters/ pamphlets, billboards/ banners, and the internet.
\end{abstract}

Keywords: Vasectomy, Acceptors, Family Planning.

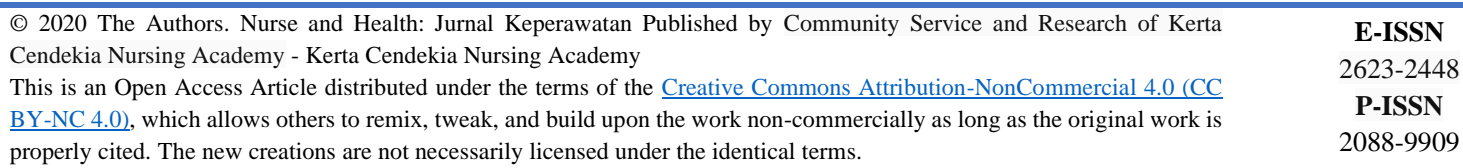

E-ISSN

2623-2448

P-ISSN

2088-9909

Indonesia is a developing country which every year is one of the largest contributors to the world 's population, even though the government has launched a family planning program in the last decades. Family planning is also one of the four pillars of safe motherhood apart from the other 3 pillars, namely antenatal care, clean and safe delivery, and essential obstetric services. Family planning is here to play a role in ensuring that each person/ couple has access to family planning information and services so that they 
can plan the right time for pregnancy, pregnancy spacing, and the number of children. Thus, it is hoped that there will be no unwanted pregnancies and pregnancies that do not belong to "4 too", namely too young, too old to get pregnant, too often pregnant, too many children (Sarwono, 2009).

There is an increased percentage of use of contraceptives (all the way) to the Indonesian Demographic Health Survey (IDHS) from 62 percent in 2012 to 64 percent IDHS at IDHS 2017. However, the percentage of breaking Disposable (Drop-Out) participation of family planning remain high at 34 percent. Then there are still large spouses of fertile age (PUS) to unserved and not using contraception, as seen from the percentage of married women aged 15-49 with family planning needs unmet (unmet need) by 11 percent (BKKBN, 2020). The factor of the lack of success of the family planning program cannot be separated from the lack of interest in the community, especially couples of childbearing age (PUS) using contraceptives. Most of them still consider the high cost and uneasy service to use steady contraception methods.

The steady method of contraception is a method of contraception which in men is called a vasectomy and in women is called a tubectomy. Steady contraception in women called tubectomy is an operation by means of mini laparotomy (minilab), which is an action on a woman's fallopian tube through a small incision in the abdominal wall $\pm 2-3 \mathrm{~cm}$ which can result in the woman being unable to become pregnant. While vasectomy is a term in surgery which is formed from two words, namely vas and ectomy. Vasectomy is a partial cut $(0.5 \mathrm{~cm}-$ $1 \mathrm{~cm})$ in the vasa differentia or light surgery by binding and cutting the vas deferens so that sperm cannot pass and the semen does not contain spermatozoa, so that fertilization does not occur, this method uses less surgical techniques. more than 15 minutes and the patient does not need to be treated. The formed sperm will not be released by the body, but will be absorbed and destroyed by the body (Mulyani and Rinawati, 2013).
Based on data from the 2017 Indonesian Demographic and Health Survey (IDHS), the percentage of male contraceptive use using condoms is $2.5 \%$ and vasectomy is $0.2 \%$. One of the factors causing male family planning participation is still low, namely the limited acceptance and accessibility of family planning services for men because the distribution and distribution of doctors who are able and able to provide vasectomy services is not evenly distributed in Indonesia. The 2017 IDHS also states that 30 percent of married women and 34 percent of married men are not exposed to family planning messages through one of the six media sources (television, radio, newspapers/ magazines, posters/ pamphlets, billboards/ banners, and the internet).

In addition to the above factors, the low interest of the men to be acceptors of vasectomy is of the assumption or myth that speckle m necessarily true one is when men g using contraception vasectomy then the man will lose his manhood and could not get an erection optimally while doing coitus together partner, another factor that is no less important is the husband's lack of attention to the impact of family planning on a wife, especially when using hormonal birth control. Many men think that family planning is a woman's obligation, so that there is no obligation for men to become family planning acceptors if the couple doesn't want a child to be present.

The achievement of new family planning acceptors is also inseparable from social support for the success of the family planning program. Social support is support obtained from interpersonal relationships which refers to pleasure, calm, useful assistance in the form of verbal information received by a person from another person or other group that has a behavioral effect on the recipient. Social support can be in the form of providing information, behavioral assistance, or material obtained from close social relationships that can make individuals feel cared for, valued, and loved. The availability of social support will make individuals feel loved, valued, and part of the group. 
Based on Karr's theory in Notoatmodjo (2010), an action is determined by five determinants. The fifth form of the determinant is the intention (intention) to act, social support (social-support), accessibility of information (accessibility of information), personal freedom (personal autonomy) and the situation allows (action situation).

There are several factors that make men reluctant to take family planning, including low knowledge and understanding of reproductive rights, limited male contraceptives, social conditions, rumors about vasectomy and negative condom use (Notoatmodjo, 2010). Knowledge is a big factor in increasing men's participation in family planning. Human behavior is the result of knowledge, if knowledge is lacking then the urge to act is lacking.

Knowledge is given in the learning process which of course uses media or assistive tools even though in essence the learning media is not what determines the only learning outcome. Learning media in general is a tool for teaching and learning. Can also be interpreted as anything that can be used to stimulate thoughts, feelings, attention and abilities or skills so as to encourage the learning process (Woolfolk, 2001). There are several objectives of using learning media, namely to facilitate the teaching and learning process, increase the efficiency of teaching and learning, maintain relevance to learning objectives, and help concentration. When this has been done health promotion. This method is one of the steps in an effort to increase health knowledge which leads to a person's attitude and behavior.

Health education is a learning activity designed by nurses according to client needs. Achieving health education goals will be easier with the use of appropriate learning media and can increase the ease of receiving information. According to Nies and Mc Ewen (2001) the use of tools in the form of writing will result in increased knowledge rather than words.

One's knowledge of health can be obtained through health education. Ali
(2019) revealed that health education is an educational activity carried out by spreading messages, instilling confidence, so that people are not only aware, know and understand, but also want and they can do something. advice that has to do with health.

Learning media or health education media that can and quickly deliver health messages include: television, radio, newspapers/ magazines, posters/ pamphlets, billboards/ banners, and the internet.

With the media above, the public is more easily exposed to information, especially about health so that they can increase their knowledge and can take positive attitudes or behaviors in terms of health, such as being willing and fully aware of supporting family planning programs by becoming family planning acceptors, especially vasectomy.

\section{ACKNOWLEDGMENT}

None.

\section{DECLARATION OF CONFLICTING INTEREST}

None.

\section{FUNDING}

None.

\section{AUTHOR CONTRIBUTION}

Agus Sulistyowati: Compile the manuscript.

Ni Putu Widari: Assist in compiling the manuscripts.

\section{ORCID}

\section{Agus Sulistyowati}

None.

\section{Ni Putu Widari}

None.

\section{REFERENCES}

Ali, Z. (2019). Professional Nursing Basics. Jakarta: Widya Medika.

BKKBN. (2010). Family Planning Information and Services. Jakarta: BKKBN. 
BKKBN. (2020). Keluarga Berencana dan Kesehatan Reproduksi. Jakarta: BKKBN.

Mulyani S.N. \& Rinawati M. (2013). Keluarga Berencana dan Alat Kontrasepsi. Yogyakarta: Nuha Medika.

Nies, MA, \& McEwen, M, (2001). Community health nursing: Promoting the health of population (3rd ed.). USA: WB Saunders Company.

Notoatmodjo, Soekidjo. (2010). Health

Promotion and Behavioral

Science. Jakarta: Rineka Cipta.
Harisya, R. (2014). Relationship between husband's knowledge and use of the contraceptive mastectomy method. Journal of Nursing, 10 (2).

Sarwono. (2009). Ilmu Kebidanan. Jakarta: Yayasan Bina Pustaka.

Woolfolk, A. E. (2001). Educational psychology (8th ed.). Boston: Allyn and Bacon.

Cite this article as: Sulistyowati, A., Widari, N. P. (2020). Efforts to increase interest in vasectomy family planning acceptors. Nurse and Health: Jurnal Keperawatan, 9 (2), 240-243. https://doi.org/10.36720/nhjk.v9i2.214 